Kirsten E. Thorsen

Department of Primary and Secondary Teacher Education

Oslo and Akershus University College of Applied Sciences

Email: Kirsten.Thorsen@hioa.no

\title{
Practice Teachers’ Role in Teacher Education - Individual Practices across Educational Curricula
}

\begin{abstract}
Practice teachers have a central role in teacher education. However, research indicates randomness and obscurity in performing this role. The research project "Teachers' Professional Qualifications" (TPQ) examines objectives regarding the new Teacher Education Reform in Norway from 2010 in a broad perspective. As the reform places high demands on practice teachers as equal participants in teacher education, this article examines how they perceive their roles and tasks with respect to the intentions. The study is based on a survey of 45 practice teachers and in-depth interviews with eight others.

The main results reveal that the role of practice teachers as mentors is based on significant experience as school teachers and that general teacher activities are more focused than the claims of the educational programs. Practice teachers seem to legitimate their role outside of the context of teacher education. The study also seems to confirm what international research strongly indicates: the need to involve and cooperate with practice teachers to increase coherence in theoretical studies and school practice.

Four years after the implementation of the reform, there are reasons to question the degree to which the reform intentions have been realized. The discussion is related, in particular, to the professionalization of the role of the practice teachers and their role as cooperating participants in teacher education.
\end{abstract}

Keywords: teacher education, teacher educators, practice teachers, theory-practice relationship

\section{Sammendrag}

Praksislcerere har en sentral rolle i lcererutdanning. Forskning peker imidlertid på at både tilfeldigheter og uklarheter er knyttet til utøvelse av rollen. Forskningsprosjektet "Teachers" Professional Qualifications" (TPQ), undersøker intensjoner med den nye lcererutdanningsreformen i Norge i et bredt perspektiv. Denne artikkelen undersøker hvordan praksislerere oppfatter sin rolle og sine oppgaver på bakgrunn av at reformen har ambisjoner om praksislcerere som likeverdige samarbeidspartnere i lcererutdanning. Studien har utgangspunkt $i$ en spørreundersøkelse med 45 praksislcerere i tillegg til dybdeintervju med åtte andre.

Resultatene viser at det som kjennetegner rollen som praksislcerer, først og fremst er lang erfaring som larer. I tillegg viser resultatene at generelle lareroppgaver har mer oppmerksomhet $i$ praksisperioder enn det som er mål i lcererutdanningsprogrammet. På den måten legitimerer praksislcerere sin rolle ut av en lcererutdanningskontekst. Studien bekrefter også det internasjonal forskning viser: behovet for å involvere praksislcerere i felles prosesser for å utvikle sammenhenger mellom teoristudier og praksisopplcering i lcererutdanning.

Fire år etter implementering av leererutdanningsreformen $i$ Norge er det grunn til å stille spørsmål ved i hvilken grad intensjonene i reformen har blitt realisert. Diskusjonen er i hovedsak knyttet til profesjonalisering av praksislcererrollen og praksislcerere som likeverdige samarbeidspartnere i lcrerutdanning.

Nøkkelord: læererutdanning, læererutdannere, praksislærere, forholdet teori-praksis 


\section{Introduction}

A practice teacher has a key role in teacher education. She has great responsebility, and she is considered as highly credible by student teachers during periods of school practice (Bullough \& Kauchak, 1997; Nilssen, 2010; Shulman, 1998). However, educational research shows that practice teachers have an unclear vision of their role as mentor and interpret the aims and content of practice in different ways (Clarke, Triggs, \& Nielsen, 2013; Darling-Hammond, 2006; Korthagen, 2008; Zeichner, 2010). The complexity of mentoring, by its nature, implies different approaches to the field. Mentoring, which involves a personal relationship between the practice teacher and the student teacher, is affected by the local context and involves a developmental process related to the defined aims and content of the educational program (Ambrosetti \& Dekkers, 2010). As there seem to be tensions between practice teachers' daily tasks and activities in the classroom and claims in educational programs of teacher education, this article focuses on mentoring as a developmental process, as well as understanding practice teachers as participants within an educational framework of teacher education programs. The research question addressed is: How do practice teachers in teacher education conceive their roles as mentors, given the tension between professional responsibilities and commitments in school and the intended aims and content of teacher education?

In the following section, the national intentions of the Norwegian teacher education reform from 2010 are presented. An overview of previous international research in the field of teacher education illuminates the research question with perspectives related to the role of the practice teacher, aims and content of school practice, and the collaboration between the different actors in teacher education. The article then presents and analyses the findings of a questionnaire answered by 45 practice teachers and in-depth interviews conducted with eight others. The findings are then discussed in light of previous research and the current reform of Norwegian teacher education. The intention of this article is to contribute to the field with the perspective of the practice teachers and more exactly to illuminate and explore how the practice teachers perceive their role.

\section{Teacher Education in Norway}

In line with international studies, one of the main conclusions of the evaluation of Norwegian teacher education in 2006 (NOKUT, 2006) is a weak coherence between theoretical studies at the university colleges and what is focused on in school practice. Based on this, the overall purpose of the teacher education reform of primary and lower secondary schools in Norway from 2010 is to promote an integrated teacher education. National guidelines describe the aims and content of school practice as learning outcomes related to the topics of the pedagogical curricula for each year of the educational program. The guidelines 
thus intend to make connections between theory and practice in what appear to be formulations for the conceptual coherence in the theoretical and practical curricula.

Furthermore, the national guidelines emphasize the importance of the university colleges' responsibility to organize and formalize cooperation between teacher educators and practice teachers in order to realize the idea of an integrated teacher education. The substantial content of the cooperation is, however, expressed in general ways with statements like "creating a common platform" and "integration of theory and practice", making practice an integral part of teacher education (Kunnskapsdepartementet, 2010).

The teacher education reform also aims to strengthen the teachers' competence in core subjects, particularly for the needs of lower secondary school. For educating teachers for both primary and secondary school, Norway from 2010 offers two different teacher educations for the two schools; grades 1-7 and grades 5-10.The overall purposes are common, though the subject curricula differ.

In Norwegian teacher education, the practice teacher should be a class teacher in primary and/or lower secondary school, and the head of school is responsible for ensuring the suitability of the chosen mentor as a skilled school teacher (Kunnskapsdepartementet, 2005). The national guidelines also require practice teachers to have an additional education of 15 ECTS in mentoring, and teacher education institutions are required to facilitate this mentoring education by providing 30 ECTS.

\section{Previous Research}

Several studies indicate that it is highly random what type of role the practice teachers assume for themselves during practice. The recruitment of practice teachers involves very few quality standards or requirements. They are often assigned the duties of a practice teacher and declared a practice teacher without being required to have any formal qualifications. The additional role as a teacher educator is unclear, and research shows that lack of qualifications and understanding of the role may imply unclear expectations regarding the development of student teachers' professional knowledge (Darling-Hammond, 2010; FeimanNemser, 2001; Graham, 2006; Russel \& Russel, 2011).

A matter of significance in relation to the role and duties of the practice teacher is the fact that the practice teacher must simultaneously combine two different professional roles. On the one side, she is the school teacher of the pupils in her class, and, on the other, she is the professional mentor for student teachers. This dilemma raises questions about the primary focus during periods of practice. Tynjälä (2008) identifies this as a challenge in vocational education in general, and refers to findings stating that educational matters concerning the student teachers are of secondary concern in the workplace. Moreover, a review of literature addressing practice teachers' participation in teacher education 
confirms this picture, indicating that practice teachers' primary focus is on their pupils, more than on the student teachers (Clarke et al., 2013).

The overall formal aim of school practice in teacher education is to develop a coherent understanding of theoretical and practical knowledge for student teachers (Grossman, Hammerness, \& McDonald, 2009; Korthagen, 2008). This aim reflects the classical issue of the connection between theory and practice in vocational education. A major challenge in teacher education is the disparity between the different forms of knowledge of theory and practice. The idea of application of theory in school practice still dominates and impacts the role of the practice teacher. Research shows that practice teachers often feel inferior to the academic knowledge represented by the university college, and do not consider themselves as competent in handling principles and theories in the field of education (Koster, Lagerwerf, \& Wubbels, 2006; Zeichner, 2010). Practice teachers are instead more familiar with personal and contextual pedagogical knowledge acquired from working as school teachers for an extended period of time (Clarke et al., 2013; Joram, 2007; Shulman \& Shulman, 2004). Another dominant trait regarding the content of school practice seems to be that practice teachers often have unclear ideas of what professional themes should be in focus. Practice is described as "left to chance", and the educational framework or curriculum, in which institutional expectations are to be presented, seems to a small degree to affect the content of school practice (Graham, 2006; Grossman et al., 2009; Mattsson, Eilertsen, \& Rorrison, 2011).

Lack of curricular content in practice and practice teachers having an experience based, contextual approach to teaching, affect student teachers' learning processes in practice (Darling-Hammond, 2010; Joram, 2007; Graham, 2006). Valid knowledge of teaching is then possessed by the practice teacher and her activities in the classroom, and she may thus emerge as a model for the student teachers learning to handle practice. An apprenticeship model of learning in practice has a long tradition in vocational education, and we distinguish between a person centered and decentered approach. A person centered approach focuses on the relation between the mentor and the apprentice as well as learning by observation and imitation. A decentered approach emphasizes participation in a specific social context more than the personal qualities of the mentor. This approach is developed into a theory of situated learning, which violates a traditional view of learning as an individual internalization of knowledge. In a situated perspective the knowledge is distributed between those who participate in the social situation, as well as the routines and actions going on (Nielsen \& Kvale, 1999; Lave \& Wenger, 2005).

In an effort to bring forth professional challenges and to create a better balance between theory and practice, teacher education curricula for realistic teacher education in the Netherlands are organized around the practical concerns of new school teachers as a starting point through which theory is introduced (Korthagen, 2008). Grossman et al. (2009) argue, in line with this, for placing 
what they call "core practices" of the profession in the center of the curriculum. Core practices go beyond general practical needs and are described as highly frequent practices which invite student teachers to learn about the complexity of teaching, e.g. leading classroom discussions. Focusing on core practices implies that teacher educators at the university college must tend to both the conceptual and clinical aspects of practice, and that the content of school practice is predictable and well-prepared. The conceptualization of the relationship between theory and practice with respect to educational aims and purposes is of fundamental importance for a common understanding between teacher educators and practice teachers, and as a foundation for the attainment of student teachers' learning outcomes (Grossman et al., 2009; Tynjälä, 2008).

Communication between the participants in teacher education programs is essential for how practice teachers perceive their role, as well as the aims and content of school practice. As communication is a complex process (Jensen \& Ulleberg, 2011), it has to be viewed in terms of what characterizes the relationship between practice teachers and teacher educators as well as the substance of the cooperation. Research strongly indicates that the cooperation between university colleges and schools is a central challenge in teacher education (Korthagen, 2008; Ohnstad \& Munthe, 2008; Zeichner, 2010). In the review of research on practice teachers, Clarke et al. (2013) show that university colleges are the focal point of the cooperation, representing the authority in the relationship. In this way, the cooperation reflects a relationship of power between schools and university colleges regarding the practice teachers as the ones cooperating with the university college. As the traditional perspective in teacher education views academic knowledge as the authoritative source of knowledge, along with a "theory applied to practice" view, cooperation tends to be thought of as the university colleges transferring knowledge to the practice teachers (Erault, 2004; Koster et al., 2006; Zeichner, 2010).

It further seems to be a crucial issue that teacher educators and practice teachers together discuss the relationship between theory and practice. DarlingHammond (2010) and Graham (2006) show, for example, that seminars and dialogues organized as team models seem to strengthen the relationship between the different participants in teacher education for the mutual benefit of both parties. Tynjälä (2008) emphasizes the importance of having a shared understanding of the learning goals, especially as the assignment as mentors is of secondary interest for the practice teachers. Practice teachers participating in developing the curriculum will potentially improve and strengthen the practicetheory connection and also ensure educational plans for teacher education which are consistent with current challenges (Korthagen, 2008; Tynjälä, 2008; Zeichner, 2010). Practical concerns at the center of the curriculum will contribute to a feeling of ownership among practice teachers and make cooperation more meaningful. This may also challenge the lack of a coherent vision of teaching and learning as a general challenge in teacher education and as a 
common philosophy that reflects central aspects of learning and teaching in both the theoretical and the practical part of teacher education (Grossman et al., 2009; Hammerness, 2012; Korthagen, 2008).

\section{Methods}

With international research as a backdrop, data from the project “Teachers' Professional Qualifications” (TPQ) are used to examine the research question. The study in this article is based on data from two different sources: a questionnaire anonymously answered by 45 practice teachers at one university college and indepth interviews conducted with eight others, representing two different university colleges.

The data were collected in 2013/14. The respondents to the questionnaire were practice teachers for student teachers at a university college in an urban city in Norway, and the survey was conducted at the conclusion of a meeting at the university college. The questions asked were related to their own experiences as practice teachers with respect to the qualifications necessary for this role, their ability to support the student teachers in their learning process, their knowledge about policy documents and their cooperation both among themselves and with the university college. The questionnaire was formulated as open answer questions. Perhaps because the questionnaire was conducted at the end of a meeting, the length of the answers to questions varied, as some participants provided answers of three to four sentences while others simply answered "yes" or "no". Providing the respondents with more time to answer the questionnaire would probably have affected the quality of the data set. The answers available as full text were categorized in accordance with the questions asked. The short responses were noted and served as a backdrop to more general tendencies.

Four of the respondents to the in-depth interviews were practice teachers at a university college in a larger city, while the remaining four were affiliated with a smaller university college in Norway. The coordinator for school practice at each university college was asked to contact the head of school at two different practice schools which were engaged in positive cooperation with the university colleges, one school receiving grades 1-7 student teachers and another receiving grades 5-10 student teachers. Each head of school was further asked to select practice teachers who were experienced, and who could be characterized as active and dedicated practice teachers. The interviews were based on questions regarding the intentions of the teacher education reform in general. Information of relevance for this study included: the practice teachers' identity as teacher educators, the relevance of a research-based teacher education for the student teachers' reflection on practice, how theory acquired on campus and experiencebased knowledge can complement each other, the cooperation between the practice teachers and the subject teachers at university colleges and how the 
practice teachers get support from the head of school and other colleagues. The in-depth interviews thus gave opportunities to elaborate the issues from the questionnaire. The interviews have been audiotaped and transcribed.

In a thorough reading process, I have let the text speak for itself. In the first instance to structure the data, three core categories appeared as obvious: qualifications, aims and contents of practice, and cooperation with the university college. In the process of coding, I identified excerpts belonging to the different categories. I then sorted the texts in each core category into subcategories to get a more nuanced understanding of these complex questions. In an open process of coding (Glaser \& Strauss, 1967), I have searched to identify themes and patterns to illustrate the research questions. The texts that were developed from the answers to the questionnaire were added to the texts from the interviews to form a coherent text. Accordingly, I have not separated them when referring to statements in the findings below.

\section{Findings}

\section{Qualifications of Importance}

Most respondents stressed extensive experience as school teachers as an important characteristic for being a practice teacher. In addition, many of them mentioned that they had solid subject matter knowledge and were good classroom leaders: “... fifteen years of practice, good at classroom leadership, I appreciate to reflect upon my own practice, solid subject matter knowledge". Some also pointed out that they were teachers who received a lot of positive feedback: "I am a skilled teacher in the subjects I teach and I get positive responses." Other aspects that were salient for respondents were more interpersonal, relational qualifications, described in terms such as "engaged", "humble”, "generous", "trusting”, "responsive”, and "empathetic". One noted: "I can challenge the student teachers in a soft way. My strength as a teacher is classroom leadership and social competence. The students learn a lot from me as a model teacher." Most respondents highlighted aspects of themselves as being suitable in a role of mentoring, but it is worth noting that less than one-sixth of the cohort reported having any formal education in mentoring. A large percentage of the respondents used the word "we", indicating an equal relationship with the student teachers in statements about the relationship between mentors' and student teachers' relational competence. These statements included "we plan together to ensure the pupils' learning" and "mainly we help each other so we reach the aims of learning". Moreover, many of the respondents expressed a positive view of the student teachers, viewing them as a set of extra hands in the classroom and as a source of new ideas and inspiration. 


\section{Aims and Content of the Practical Learning}

In this category, I have tried to capture what the practice teachers described as aims and content for periods of school practice. The descriptions were about how they interpreted and related to program plans and other official information, and how they, in general, expressed the substance of practical training. Few of the respondents referred to formal curricula, and for those who did, they did not consider these useful for practical learning. For example, one respondent stated: "And then the curriculum is to correspond with everyday activities filled with yes everything." Another noted: "There were a few things [in the curriculum] which made it difficult to use - in this class in particular." For many of the practice teachers in the cohort, the defined aims and content seemed to be diffuse. Many expressed uncertainty as to exactly which topics were to be focused on in practice and what their role concerning these was supposed to be, as seen in the following statements: "I would have liked to have more accurate information of what is expected of me" and "I would have liked more training in what they, for instance, expect from observation." Some respondents also did not seem to have comprehended the conceptual coherence as formulated in the substantive topics in program plans, but instead distinguished between what they perceived as theory, on the one hand, and practice, on the other: "My student teachers were more concerned about practice than theory; I would have liked to be more familiar with the theoretical topics beforehand to more easily guide them in relation to that." "We focused on the themes which had been focused on in university courses. But I felt I knew too little about theory ..."

The data strongly suggest that practice teachers experience a fairly free arena for action, and that the schools' local plans provide the guidelines for the practical training rather than the university college's educational plans: "As long as the practice is as open as now and the school can follow the local plans ..." "The student teachers have to work in accordance with our local aims.” Furthermore, many of the respondents described the content of practice as the general professional tasks of a classroom teacher: "They participate in all that happens, and follow me at all levels as a teacher." "We are all the time dealing with the responsibilities of the teacher in the classroom."

\section{Cooperation and Communication between the University Colleges and Practice Teachers}

As I understand cooperation and communication both as process and the substance in it, the responses summed up under this category show how the practice teachers described cooperation and communication and what it is about. Cooperation and communication between the two university colleges and the practice teachers were divided into three main forms: online communication, the common meetings at the university colleges, and the teacher educators' follow-up with the student teachers in periods of practice. 
When it came to communication via internet, many of the respondents expressed that much of the general information given at meetings could be distributed via webpage or email. This was expressed despite the fact that all formal documents could be found on the homepages. One respondent expressed it this way: "Don't invite [us] to meetings that could be resolved with an email." A small number of the respondents stated that the information given on the homepages was inaccessible: “... the webpage and written material can be difficult to find and at times difficult to interpret."

The meetings at the university colleges were arranged in various ways, both as large, plenary meetings and in a smaller, seminar-like format where practice teachers and teacher educators from various specific courses in teacher education met. The data reflect variation in how practice teachers experienced the cooperation on campus in general. Regarding the joint meetings, about one-half considered them satisfying. One explained: "Good that I get relevant information and answers to the questions I have", while another noted that meetings were "very useful; things were clearer to me". Those who felt negative about the common meetings related their comments both to structure and content of the meetings: "The meetings are a little messy, cooperation about requirements, focus points, I feel I get very little information.” Another expressed it this way: "At the meetings there are formalities; they tell us what we are to do." Yet another respondent added: "We are on two different planets."

When it came to the meetings in the smaller, seminar format, a few pointed out that teacher educators did not seem to bother with the student teachers' practice at all, but in general these meetings were perceived more positively than larger joint meetings. For many of the respondents, it seemed to be of great value to gain insight into the coursework of the different subjects in teacher education: "One of the teacher educators gave a lecture he also had given to the student teachers. That was okay because then the student teachers and I had the same frame of reference." Another remarked: "What is most important to me is to have knowledge about the syllabus, so that I know what I can let the students start with." Some also referred to personal interest in these kinds of meetings: "They [the teacher educators] are positive and engaged. They do projects that are interesting to hear about." The data show the relevance of sharing information about subject content; however, the practice teachers did not seem to be involved as participants in collaborative processes.

The cooperation with the teacher educators, who were following up on the student teachers during their practice periods, seemed to be unpredictable and random. The practice teachers expressed that it was nice to be visited, but that there were neither defined aims nor particular preparations for the visit: "He was here, but I didn't feel he was very participatory.” Another respondent explained: "He had an observer's role, then he had one to one chats, so insofar I didn't speak much to him." 


\section{Discussion}

To summarize, the practice teachers have great belief in themselves and consider themselves skilled school teachers, especially in regard to subject knowledge and classroom leadership. In accordance with what is reflected in the survey and interview data, extensive teaching seems to be the underlying explanation of these views. The fact that the headmaster of the school has picked them out as practice teachers may also reinforce this view. Many reported having interpersonal personal skills and competence, which seems to be reasons to view themselves as good role models. When it comes to how practice teachers perform their roles, it was particularly interesting that many expressed what they do in a "we" form. Practice is about how the student teachers and the practice teacher together solve challenges in the classroom, as they consider the student teachers a resource in the classroom. This presents a picture of practice teachers as fairly unattached in performing their roles. This is reflected in other research which shows that the practice teacher is primarily the teacher for the pupils in her classroom, and that guiding the student teachers is an extra task subordinated to their main duties (Clarke et al., 2013; Tynjälä, 2008). However, the findings that practice teachers view the student teachers as collaborators in the daily activities with the pupils, expand this perspective.

The study reveals that the student teachers are incorporated in everyday activities, sharing responsibilities and emerging challenges with the practice teacher. In line with that, mentoring in school practice can be associated with a decentered approach of an apprenticeship model of preparing new teachers. The student teachers take part in a community of practice together with the practice teacher and share common duties. The skills and knowledge of the profession are thus learned in a work setting with an expert as the more competent mentor for the apprentice (Lave \& Wenger, 2005). This model of mentoring is based on dealing with different professional challenges as they emerge and thus conflicts with the purposes of the new reform of teacher education in Norway. The national guidelines define expected learning outcomes in placement for each year of the study. These are systematically linked to measures of the pedagogical subject in a given progression, and are moreover emphasized as guidelines to be complied with in the practice teacher's mentoring (Kunnskapsdepartementet, 2010).

The study suggests that many of the practice teachers have an unclear understanding of the educational aims and content of practice. The content is described as the general professional tasks of a teacher, and the local plans of the school seem to be guidelines for the student teachers' work more than the curriculum of teacher education. When the curriculum is mentioned, it seems to be adapted to daily activities in the classroom. This underpins the impression that practice teachers have somewhat free rein to both construct their roles and make decisions regarding the content of school practice. 
Practice teachers pointed out that the cooperation with campus revolves around two main issues, one of information exchange related to administration and practical affairs and another related to educational matters of the student teachers. They seem, in general, to be more positive and enthusiastic about smaller meetings with teacher educators, when the issue is about what the students learn on campus. This is regarded as interesting and useful to their work. The topics of smaller common meetings with teacher educators, however, are referred to as "theory" in the sense of what course studies cover. Besides reflecting a dichotomous view on theory and practice, the findings regarding cooperation show that the practice teachers have no influence on what topics are being included on the agenda of the meetings. They are presented with topics selected by the teacher educators, which seem to fit into the picture of the university college having the authority to decide what knowledge is of importance (Clarke et al., 2013; Zeichner, 2010). The national guidelines of Norwegian teacher education highlight the knowledge exchange between practice teachers and teacher educators as being of central importance for the development of coherence between course studies and practical training in schools. With this in mind, it is interesting that none of the practice teachers in the surveys and the interviews mentioned topics related to professional practices in schools as themes focused on in the common meetings. This is also in contrast with research which argues that cooperation around a curriculum reflecting professional issues is significant for the development of coherence in teacher education. Moreover, practical concerns as a common starting point for cooperation seem to contribute to equality in the relationship between teacher educators and practice teachers (Darling-Hammond, 2010; Grossman et al., 2009; Hammerness, 2012; Korthagen, 2008).

The findings show that the respondents do not refer to themselves as participants in what is meant to be a cooperation. They are given lectures, and they are told about subject content. This confirms what research shows regarding the university colleges transferring knowledge to the practice teachers, and the practice teacher as the cooperating part (Clarke et al., 2013). Being invited into an educational context more as a spectator than a collaborator may leave the practice teacher in an inferior position. The study seems to confirm what other research affirms as a concrete challenge in teacher education: to involve the practice teachers in collaborating processes discussing and developing perspectives of content and other central issues concerning coherence in course studies and school practice.

\section{Concluding Remarks}

This article discusses how practice teachers perceive their roles as mentors, given the tension between professional commitments in school and the aims and 
content in teacher education. The study the article is based on has a limited scope and does not provide sufficient data to generalize findings. However, I obviously find correlations between the data in the questionnaire and the interviews. The descriptions given by the practice teachers provide critical points for further exploration and research.

Practice teachers legitimize their roles by defining themselves as being skilled practitioners and seem to feel free to both construct their roles and make decisions concerning school practice, where general daily activities in the classroom seem to dominate. The respondents referred only marginally to the curriculum for teacher education, which thus seems to have a weaker impact than expected. The study indicates that, four years after the implementation of a new teacher education reform in Norway, there still is substantial distance between the intentions formulated in the national curriculum for practice, with practice teachers as cooperating participants, and how the practice teachers conceive their roles and their participation in teacher education.

There seems to be a need to professionalize and frame the role of the practice teacher in the context of teacher education. In this study, only a small number of the practice teachers have had additional education in mentoring. This tendency corresponds to what international research finds as a general challenge in teacher education: practice teachers may not only be haphazardly selected, but also lack appropriate education (Darling-Hammond, 2010; Korthagen, 2008; Russel \& Russel, 2011; Zeichner, 2010). Practice teachers with formal education in educational mentoring will have far better preconditions to perform their roles as teacher educators in a given educational program. Practice teachers who thus are more aware of their roles for these educational purposes will most likely contribute to a more equal relationship between the actors of the two different arenas of teacher education. The university colleges for their part face challenges in rethinking both organization and methods of knowledge exchange to make cooperation with practice teachers more meaningful.

\section{References}

Ambrosetti, A. \& Dekkers, J. (2010). The interconnectedness of the roles of mentors and mentees in pre-service teacher education mentoring relationship. Australian Journal of Teacher Education, 35(6), 42-55.

Bullough, R.V., Jr. \& Kauchak, D. (1997). Partnerships between higher education and secondary schools. Some problems. Journal of Education for Teaching: International Research and Pedagogy, 23(3), 215-234.

Clarke, A., Triggs, V., \& Nielsen, W. (2013). Cooperating teacher participation in teacher education: A review of the literature. Review of Educational Research, 84(2), 163-202.

Darling-Hammond, L. (2006). Powerful teacher education. Lessons from exemplary programs. San Francisco: Jossey-Bass.

Darling-Hammond, L. (2010). Teacher education and the American future. Journal of Teacher Education, 61(1-2), 35-47. 
Erault, M. (2004). Transfer of knowledge between education and workplace settings. In I. Rainbird, H. Fuller, \& A. Munro (Eds.), Workplace learning in context (pp. 201-222). London: Routledge.

Feiman-Nemser, S. (2001). From preparation to practice: Designing a continuum to strengthen and sustain teaching. Teachers College Record, 103(6), 1013-1055.

Glaser, B. G. \& Strauss, A. L. (1967). The discovery of grounded theory: Strategies for qualitative research. Chicago: Aldine Publishing Company.

Graham, B. (2006). Conditions for successful field experiences: Perceptions of cooperating teachers. Teaching and Teacher Education, 22, 1118-1129.

Grossman, P., Hammerness, K., \& McDonald, M. (2009). Redefining teaching, re-imagining teacher education. Teachers and Teaching: Theory and Practice, 15(2), 273-289.

Hammerness, K. (2012). Examining features of teacher education in Norway. Scandinavian Journal of Educational Research, 57(4), 400-409.

Jensen, P. \& Ulleberg, I. (2011). Mellom ordene. Kommunikasjon i profesjonell praksis [Between the Words. Communication in Professional Practices]. Oslo: Gyldendal akademisk.

Joram, E. (2007). Clashing epistemologies: Aspiring teachers', practicing teachers', and professors' beliefs about knowledge and research in education. Teaching and Teacher Education, 23, 123-135.

Korthagen, F. A. J. (2008). Linking practice and theory. The pedagogy of realistic teacher education. New York and London: Routledge.

Koster, B., Lagerwerf, B., \& Wubbels, T. (2006). Linking practice and theory: The pedagogy of realistic teacher education. Mahwah: Lawrence Erlbaum Associates.

Kunnskapsdepartementet. (2005). Rundskriv F04 05 Øvingslæreravtalen [Agreement of Working Conditions for Practice Teachers].

Kunnskapsdepartementet. (2010). Nasjonale retningslinjer for fagene i grunnskolelcererutdanningen [National Guidelines for the Subjects in Teacher Education]. Oslo: Kunnskapsdepartementet.

Lave, J. \& Wenger, E. (2005). Situeret læring og andre tekster [Situated Learning and other Texts]. København: Hans Reitzels forlag.

Mattsson, M., Eilertsen, T. V., \& Rorrison, D. (2011). A practicum turn in teacher education. Rotterdam: Sense Publishers.

Nielsen, K. \& Kvale, S. (1999). Mesterlære. Læring som sosial praksis [Apprenticeship Learning. Learning as Social Practices]. In K. Nielsen \& S. Kvale (Eds.), Mesterlcre. Lcering som sosial praksis (pp. 17-33). Oslo: Ad Notam Gyldendal.

Nilssen, V. (2010). Praksislereren [The Practice Teacher]. Oslo: Universitetsforlaget.

NOKUT. (2006). Evaluering av allmennlcererutdanningen i Norge: Hovedrapport, del 1 [Evaluation of Teacher Education in Norway. The Main Report, part 1]. Oslo: NOKUT.

Ohnstad, F.O. \& Munthe, E. (2008). Ensomme svaler? En studie av praksisskolelæreres rapportering om identitet, kollektivitet og gjennomføring av praksisopplæringsperioder [Lonely Swallows? A Study of Practice Teachers' reporting of Identity, Collectivity and Implementation of Practice]. Norsk Pedagogisk Tidsskrift, 6, 471-483.

Russel, M. L. \& Russel, J. A. (2011). Mentoring relationships: Cooperating teachers' perspectives on mentoring student interns. Professional Educator, 35(1), 1-21.

Shulman, L. S. (1998). Theory, practice and the education of the professionals. The Elementary School Journal, 98(5), 511-526.

Shulman, L. S. \& Shulman, J. H. (2004). How and what teachers learn: A shifting perspective. Curriculum Studies, 36(2), 257-271.

Tynjälä, P. (2008). Perspectives into learning at the workplace. Educational Research Review, 3, 130-154. 
Zeichner, K. (2010). Rethinking the connections between campus courses and field experiences in college- and university-based teacher education. Journal of Teacher Education, 61(1-2), 89-99. 